\title{
RESPONSE OF BUFFALO CALVES EXPOSED TO FIRST AND SECOND ACUTE THERMAL SHOCKS
}

\author{
OMRAN, FAYZA I. ${ }^{1}$, M. M. SHAFIE ${ }^{2}$, G. H. ASHOUR ${ }^{2}$, M. M. YOUSSEF ${ }^{1}$ \\ and LAILA R. HASSAN ${ }^{1}$ \\ 1. Animal Production Research Institute, ARC, Dokki, Giza Egypt. \\ 2. Department of Animal Production, Faculty of Agriculture, Cairo University, Egypt.
}

(Manuscript received 27 March 2013)

\begin{abstract}
Four buffalo calves were available for this study, aged six months and weighed (BW) $118.0-119.0 \mathrm{~kg}$ at Animal Physiology Research Lab, Animal Production Department, Faculty of Agriculture, Cairo University.

The present work aimed to compare between the effect of heat shock on buffalo calves to $1^{\text {st }}$ and $2^{\text {nd }}$ acute response under exposure to artificial constant heat stress $\left(40^{\circ} \mathrm{C}\right)$. and a comparatisia between $1^{\text {st }}$ and $2^{\text {nd }}$ acute response of buffalo calves for response of thermo-respiratory responses, hematological response, plasma metabolites, hormones, feed intake and water intake.

The results obtained from this study could be summarized as follows to found reaction of buffalo calves to acute physiological response of the $2^{\text {nd }}$ shock to thermal condition at $40^{\circ} \mathrm{C}$ it is found that all parameters were best comparative with the $1^{\text {st }}$ shock. Stability of RR under this condition during the $2^{\text {nd }}$ shock indicator to the buffalo can be heat tolerance over, the white blood cells count increased as an indication of immunological activity, the values of globulin during two shocks were not significant confirm the higher immunity for buffaloes. Values of water consumption/day in two trails were not significant, for zero and trails shock may be indicator to tolerance the buffalo calves decreased the water and this trend needs more study. It could be concluded that stability of buffalo calves under this condition cousideved as an indicator to the beast animal with climatic change.

Key words: thermo-respiratory, hematology, blood metabolites, hormones, acute thermal shock condition and buffalo calves.
\end{abstract}

\section{INTRODUCTION}

Heat is the major constrains on animal productivity in arid zones. Growth, milk production, reproduction and immunity are impaired as a result of drastic changes in biological function caused by heat stress.

With climatic change during last ten years, high temperature with humidity severely depresses growth rate, milk production, reproductive efficiency of dairy cows and immunity of calf (Omran, 1999, 2008 and West, 2003). 
Housing and nutrition represent two main direct items to solve this problem but on the other hand, animal breeding under these climatic conditions can be product without over drop in production and good health. Animals have a complex physiological mechanisms which enable them to interact with their environment in various ways to fulfill the most successful maintenance and activities.

The physiological responses of ruminants towards climatic conditions involve control of heat dissipation and heat production. The subtropical animals are equipped for less production of metabolic heat and facilitated heat dissipation.

Suitability of Egyptian buffaloes to hot climate is achieved by morphological, anatomical and physiological characteristics (Shafie, 1993, Omran 1999, 2008, Omran et. al., 2011 and Omran and Fooda, 2012). Fooda, 2005 showed that, after weaning the genetic correlation coefficients among body weight at different ages were high and positive. Also, he added that body weight at 6 and 9 months of age has highly positive phenotypic and genetic correlation with other weights at the end of growth curve.

When animals are exposed to stress for long duration (chronic stress), they try to acclimatize in the adverse condition. Acclimation involves phenotypic responses to environmental changes, which are reflected in hormonal signals and also in alterations in target tissue responsiveness to hormonal stimuli. The time required for acclimation varies according to tissue types, and from a few days to several weeks, for example changes in metabolism in response to heat stress occur over a few days (Collier et. al., 2008). Alterations in physiological responses to thermal stress was found to be within 24-48 $\mathrm{h}$ in the Egyptian buffaloes to allow acclimatization of the animal against severe condition under artificial condition at $40^{\circ} \mathrm{C}$ and $25^{\circ} \mathrm{C}$ (Omran, 1999 and 2008).

The present work was conducted to compare between the acute thermal shock on buffalo calves exposure to artificial constant $\left(40^{\circ} \mathrm{C}\right)$ to study the performance of thermo-respiratory responses, hematological response, plasma metabolites and hormones, feed and water intake during $1^{\text {st }}$ and $2^{\text {nd }}$ shock.

\section{MATERIALS AND METHODS}

Four buffalo calves (BC) were available for this study, age of calves was six months and their live body weight (BW) ranged from 118.0 to $119.0 \mathrm{~kg}$. All animals were healthy and clinically free from diseases.

The experimental work was done at Animal Physiology Research Lab, Animal Production Department, Faculty of Agriculture, Cairo University and the experimental 
animals were obtained from Mehalet Mousa Experimental Farm, Animal Production Research Institute, Agricultural Research Center, Ministry of Agriculture, Egypt in order to test the thermal shock on behavioral thermo-respiratory responses (rectal temperature $\left(R T,{ }^{\circ} \mathrm{C}\right)$, respiration rate $(R R, r / m i n)$, hematological responses, concentration of some plasma metabolites and hormones, feed (FI) and water (WI) intakes.

All responses were assessed under heat stress in lab at $40^{\circ} \mathrm{C}$ constant thermal conditions. Two trials, each of 3 days, were interrupted by 15 days period under natural climatic outdoors conditions recording the air temperature (AT, ${ }^{\circ} \mathrm{C}$ ) and relative humidity $(\mathrm{RH}, \%)$ in outdoor and calculated the temp-humidity index (THI) under shed (Table 1).

Table 1. Average air temperature $\left(\mathrm{AT},{ }^{\circ} \mathrm{C}\right)$, relative humidity $(\mathrm{RH}, \%)$ and temphumidity index THI in outdoor.

\begin{tabular}{|c|c|c|c|c|}
\hline \multirow{2}{*}{ Diurnal Time } & \multicolumn{2}{|c|}{ AT } & \multirow{2}{*}{ RH } & THI \\
\cline { 2 - 3 } & Min & Max & & \\
\hline $08.00 \mathrm{~h}$ & $31.0 \pm 0.2$ & $35.0 \pm 0.3$ & $88.3 \pm 0.4$ & $89.8 \pm 0.6$ \\
\hline $14.00 \mathrm{~h}$ & $36.0 \pm 0.3$ & $38.0 \pm 0.4$ & $77.0 \pm 0.5$ & $94.4 \pm 0.5$ \\
\hline
\end{tabular}

The lab was equipped by 4 heaters controlled by highly sensitive digital thermostat alongside ceiling and suction fans. Thus, the ambient temperature (AT) in this lab was fixed and maintained exactly at $40{ }^{\circ} \mathrm{C}$, the relative humidity (RH) was $87.3 \%$ in first trial and $87.7 \%$ in second trial, the temperature-humidity index (THI) was $101.2 \pm 0.1$ in first trail and $100.8 \pm 0.1$ in second trail.

The measurements were taken at one time on day at 08:00 h. The first day zero time at 08:00 $\mathrm{h}$ in outdoor and first reading record in lab was taken after 4 hours from exposure. Feed and water intakes were determined day zero before the beginning of the experiment and value of consumption was recorded daily.

All measurements were recorded once a day at 08:00 $\mathrm{h}$ before drinking and eating except feed and water intake were determined daily at 09:00 $\mathrm{h}$ and 17:00 $\mathrm{h}$.

The following estimates were determined: Rectal temperature $\left(\mathrm{RT},{ }^{\circ} \mathrm{C}\right)$ and respiration rate $(R R, r / m i n)$, hemoglobin concentration, $(H b, g / d l)$ hematocrit value $(\mathrm{Ht}, \%)$, red blood cells count (RBCs, $x 10^{6} / \mathrm{mm}^{3}$ ), white blood cells count (WBCs, $x$ $10^{3} / \mathrm{mm}^{3}$ ), differential leukocytes counts (lymphocytes (Ly, \%), neutrophils ( $\mathrm{Ne}, \%$ ), eosinophils (Eo, \%), basophils (Ba, \%) and monocytes (Mo, \%)), concentration of total protein ( $T P, g / d l)$, albumin (Alb, g/dl), globulin (Glo, g/dl), total lipids ( $T L$, $\mathrm{mg} / \mathrm{dl})$, triglycerides (TG, mg/dl), total cholesterol (TC, mg/dl), glucose (Glu, mg/dl) and blood urea nitrogen (BUN, mg/dl), The considered hormones were determined, 
triiodothyronine $\left(T_{3}, \mathrm{ng} / \mathrm{dl}\right)$, thyroxine $\left(T_{4}, \mu \mathrm{g} / \mathrm{dl}\right)$, insulin (Ins, $\left.\mu \mathrm{IU} / \mathrm{ml}\right)$, glucagon ( $\mathrm{Glg}$, $\mathrm{pg} / \mathrm{ml}$ ) and aldosterone (Al, pg/dl).

Relevant statistical analyses of data were carried out applying the Statistical Analysis System (SAS, 2002).

\section{RESULTS AND DISCUSSION}

\section{Thermo-respiratory responses}

Table (2) and Fig. (1) shows rectal temperature $\left(R T^{\circ} \mathrm{C}\right)$ and respiration rate ( $R R, r / m i n)$ for buffalo calves before exposure to stress in lab (zero time) and under stress in lab at $\left(40^{\circ} \mathrm{C}\right)$ during $1^{\text {st }}$ and $2^{\text {nd }}$ shock.

Values of RT and RR did not significantly differ between $1^{\text {st }}$ and $2^{\text {nd }}$ zero time, however the exposure to either the first or second shock was significantly increased both RT and RR (Table 2).

Rectal temperature of calves at the $1^{\text {st }}$ day of the second shock decreased by $0.38^{\circ} \mathrm{C}$, also respiration rate decreased by $6 \mathrm{r} / \mathrm{min}$ compared with the $1^{\text {st }}$ day of the first shock.

It was observed that day zero of the $1^{\text {st }}$ shock showed high RT and RR compared with the $3^{\text {rd }}$ day $\left(2.6{ }^{\circ} \mathrm{C}\right.$ nd $\left.99 \mathrm{r} / \mathrm{min}\right)$. during the $2^{\text {nd }}$ shock, RT and RR were higher during the $3^{\text {rd }}$ day compared with zero day $\left(2.09{ }^{\circ} \mathrm{C}\right.$ and $\left.91 \mathrm{r} / \mathrm{min}\right)$.

It has been proved by several studies that buffaloes have low capability of sweating thus it depend on increased rate of respiration to insure enough water vaporization for proper heat dissipation, Kundu and Bhatnagar (1980) stated that RR plays an important role in thermoregulatory mechanism among all the physiological reactions and body temperature. The increase in respiration rate with the increasing temperature may be due to the more demand of oxygen by the tissues in stressful condition. The results of physiological responses are in agreement with the observations of Thanh and Chang (2007) and Haque et al. (2012). RT is a good measure of core temperature and has been used by many investigators as measurement to detect the response of animal to environmental conditions. RR the most sensitive index which reflects more response to the environmental conditions than the other physiological responses and at the first indicator to stress of animals (Omran, 1999, 2008 and Omran et. al., 2011). Stability of the RR under this condition at $2^{\text {nd }}$ shock is an indicator to the buffalo animal can be heat tolerance over.

\section{Hematological responses}

Tables ( $3 \& 4)$ and Fig. ( $2 \& 3$ ) show hematoctite $(\mathrm{Ht}, \%)$, hemoglobin ( $\mathrm{Hb}$, $\mathrm{g} / \mathrm{dl})$, red blood cells count (RBCs, $\mathrm{X}^{6} / \mathrm{mm}^{3}$ ), white blood cells count $\left(\mathrm{WBCs}, \mathrm{X}^{10} / \mathrm{mm}^{3}\right.$ ) 
and leukocyte differential count during zero time and during shock periods. At both zero days, the concentration of $\mathrm{Ht}, \mathrm{Hb}$ and RBCs were significantly higher than those of the three days of treatments. However, WBCs and the leukocyte types were significantly higher at the record zero day compared with the first one.

The values of $\mathrm{Ht}, \mathrm{Hb}$ and RBCs were significantly lower in the three days of the $1^{\text {st }}$ shock than those of the $2^{\text {nd }}$, but the WBCs were significantly higher in the $2^{\text {nd }}$ shock than the $1^{\text {st }}$ one. Almost all the hematological parameters were higher during the $2^{\text {nd }}$ shock compared with the $1^{\text {st }}$ one.

The drop of $\mathrm{Ht}, \mathrm{Hb}$ concentration and RBCs count may be due to reduction and oxidation activity of metabolism, thus subsequent drop in metabolic heat production, the WBCs increased as indication of immunological activity. This immunological reaction was fortified by increase in Ne against decrease in Ly and increase of Mo against decrease of Eo.

These results are in agreement with Omran, 1999, 2008 and Omran et. al., 2011 who reported that exposure of buffalo calves to artificial hot condition $\left(40^{\circ} \mathrm{C}\right)$ induced reduction in $\mathrm{Ht}, \mathrm{Hb}$, RBCs while it caused increase in WBCs, Ne and Mo., and resulted that increased of $\mathrm{Ne}$ and $\mathrm{Mo}$ as a sign of immunological invocation in buffalo calves..Many other authors found the same results under hot condition (Shafie and Badreldin 1962, Jain et al (1982), Yousef, 1990).

\section{Feed and water intake}

Table (5) and Fig. (4) shows the average daily feed and water intake for buffalo calves during the zero time, $1^{\text {st }}$ and $2^{\text {nd }}$ shock.

In general no significant differences were found in water intake in both $1^{\text {st }}$ and $2^{\text {nd }}$ shock, however the water intake increased insignificantly during the two thermal treatment compared with day zero. The concentrate intake differs significantly between zero and $1^{\text {st }}$ shock but was significant in $2^{\text {nd }}$ shock at the first day. R1 values at the first day zero were significant at first day.

The WI and FI were affected by heat stress. Water intake was increased to compensate the water losses in respiratory water vaporization for dissipating excess of heat from the body. On the other hand FI was depressed in a struggle to reduce metabolic heat production in counteraction to the hot condition. Under that severe heat load, as conducted from the ambient hot air $\left(40^{\circ} \mathrm{C}\right)$ and radiated from the hot surrounding walls and roof, is imposed on the calves as excess heat load, thus reduction of the internal heat load of metabolism.

It is clear in Figure (4) that the effect of heat stress was more prominent in the $1^{\text {st }}$ shock than in the $2^{\text {nd }}$ one. This proves that the calves were capable to exercise adaptive performance to repeated heat stress. 
Water intake (WI) is known to be affected by several factors. It increases as dry matter intake when feeds increase. Climate is the most important factor affecting water intake. Water consumption increased with the rise of AT (Ashour et. al., 2007, Omran, 1999, 2008). Mullick (1962) found $50 \%$ increase in WI during an Indian summer $\left(41^{\circ} \mathrm{C}\right)$ over that in winter $\left(11^{\circ} \mathrm{C}\right)$.

Omran (1999) found that buffalo calves drank $19.61 \mathrm{~L} /$ day under heat stress $\left(40^{\circ} \mathrm{C}\right)$ at 9 month of age, meanwhile at old ages ( $\geq 18 \mathrm{mo}$.) the value of WI was 33.6 L/day. She also found that water consumption per I kg BW ${ }^{0.75}$ was increased by $16 \%$ in heat stressed for buffalo calves.

Nangia and Gary (1992) found that the voluntary feed intake during months of higher AT was reduced to $40 \%$ as compared to that consumed during cooler months. Omran (1999) found that seasonal means of daily FI of buffalo calves was higher in winter than summer in Egypt. She reported that the percentage of roughage in the consumed ration was more in summer than in winter. Thus the ratio of roughage: concentrate ratio was higher in summer than in winter (31.3\% vs. 29.8 $\%)$. She also found that exposure of Egyptian buffalo calves to heat stress reduced concentrates intake, relating to FI. MBW proved that concentrates intake was reduced in response to heat stress, from that pre stress by $13 \%$ in that calves.

\section{Blood plasma metabolites}

Table (6) and Fig. (5) show the concentration of total lipids ( $T L, \mathrm{mg} / \mathrm{dl}$ ), total cholesterol (TC, mg/dl), triglyceride (TG, mg/dl), total protein (TP, g/dl), albumin (Alb, $\mathrm{g} / \mathrm{dl})$, globulin (Glb, g/dl), glucose (Glu, mg/dl) and blood urea nitrogen (BUN, mg/dl) during zero time of $1^{\text {st }}$ and $2^{\text {nd }}$ shock.

It was observed that TL, TC, TG, TP, Alb, Glb, Glu and BUR decreased by 47.5 $\%, 47.2 \%, 1.4 \%, 11.3 \%, 21.5 \%, 0.85 \%, 26.1 \%$ and 22.8 at the $2^{\text {nd }}$ zero day compared with the $1^{\text {st }}$ zero day, respectively. In general the concentrations of the blood components were lower during the $2^{\text {nd }}$ shock compared with $1^{\text {st }}$ one.

This may be due to the $1^{\text {st }}$ shock that caused disturbances in enzymatic reaction, hormonal secretions and blood metabolites (Collier et. al., 2008). Omran et. al., 2011, they found under heat stress in lab $\left(40^{\circ} \mathrm{C}\right)$, values of $\mathrm{TL}, \mathrm{TG}$ and TC showed highly significant decrease compared with TP, this decease of the energy from the body was to decrease the heat stress from body. Yousef, 1990 found that the depression in BUN associated with heat stress in animals may be due to more reabsorption of the BUN from the blood to the rumen to compensate the decrease in ruminal ammonia- $\mathrm{N}$ as a result of the decrease in feed intake, also addition to the increase in urine nitrogen excretion under severe heat stress conditions as indicated by negative nitrogen balance. 
Table (7) and Fig. (6) show the concentration of Insulin (Ins, Nlu/ml), Glucagons (Glg, pg/ml), Triiodothyronine $\left(T_{3}, \mathrm{ng} / \mathrm{dl}\right)$, Thyroxin $\left(T_{4}, \mathrm{Mg} / \mathrm{dl}\right)$ and Aldosterone $(A L, p g / d l)$ during zero time, $1^{\text {st }}$ and $2^{\text {nd }}$ three days for buffalo calves exposed to thermal shock $\left(40^{\circ} \mathrm{C}\right)$.

It was observed that the $2^{\text {nd }}$ zero day of exposure showed lower values of Ins $\%, \mathrm{Glg} \%, \mathrm{~T}_{3}, \% \mathrm{~T}_{4} \%$ and $\mathrm{Al}$ by $17.0 \%, 32.2 \%, 17.8 \%, 39.5$ and $13.6 \%$ compared with the concentration of the same parameters in the $1^{\text {st }}$ zero time, respectively. During the $1^{\text {st }}$ and $2^{\text {nd }}$ exposure there are a gradually decrease by time of all parameter in table (7). Only glucagon concentration in blood at the $3^{\text {rd }}$ day increased significantly in both the $1^{\text {st }}$ and $2^{\text {nd }}$ exposure periods.

Omran et. al., 2011 under artificial thermal condition found that heat stress caused decrease in Ins concentration and increased of Glg while, decreased of $T_{3}, T_{4}$ devoting a depression in general metabolic activity, thus metabolic heat production. Baccari et. al. (1990) found that thermal stress reduced the DMI and the level of serum $T_{3}$ in young buffalo calves. The metabolic heat production, decreased thyroid hormones level during heat stress is an adaptive response and also might be an attempt to reduce metabolic rate and heat production (West et. al., 2003). Changes of blood thyroid hormones concentration are an indirect measure of the changes in thyroid gland activity. A major exogenous regulator of thyroid gland activity is the environmental temperature (Dickson, 1993).

\section{CONCLUSION}

Reaction of buffalo calves to acute physiological response of the $2^{\text {nd }}$ shock to thermal condition at $40^{\circ} \mathrm{C}$ for all parameters were pronaused compared with the $1^{\text {st }}$ shock. Stability of RR under this condition during the $2^{\text {nd }}$ shock is indicator to the buffalo animal can express heat tolerance over. The WBCs increase is an indication of immunological activity, the values of globulin during two shocks were not significant, thus confirm the higher immunity for buffaloes. Values of water consumption/day in two trails were not significant for zero and shock trails this may be an indicator to tolerance of the buffalo calves however decreased the water and this trend need further study. Thus it can be concluded that stability of buffalo calves under this condition may be considered as an indicator to the best animal with climatic change. 
Table 2. Rectal temperature $\left(R T,{ }^{\circ} \mathrm{C}\right)$ and respiration rate $(R R, r / m i n)$ during zero time and first three days for buffalo calves exposured to first and second thermal shock $\left(40^{\circ} \mathrm{C}\right)$.

\begin{tabular}{|c|c|c|c|c|c|c|c|c|}
\hline \multirow{3}{*}{ Items } & \multirow{3}{*}{$\begin{array}{c}\text { First } \\
\text { Zero day } \\
26^{\circ} \mathrm{C}\end{array}$} & \multicolumn{3}{|c|}{ First Shock $40^{\circ} \mathrm{C}$} & \multirow{3}{*}{$\begin{array}{c}\text { Second } \\
\text { Zero day } \\
27^{\circ} \mathrm{C}\end{array}$} & \multicolumn{3}{|c|}{ Second Shock $40^{\circ} \mathrm{C}$} \\
\hline & & \multicolumn{3}{|c|}{ Days } & & \multicolumn{3}{|c|}{ Days } \\
\hline & & 1 & 2 & 3 & & 1 & 2 & 3 \\
\hline Rectal temperature $\left(\mathrm{RT},{ }^{\circ} \mathrm{C}\right)$ & $37.00 \pm 0.10^{c}$ & $40.13 \pm 0.25^{a}$ & $39.80 \pm 0.11$ ba & $39.60 \pm 0.15^{\text {ba }}$ & $37.33 \pm 0.06^{c}$ & $39.75 \pm 0.19$ ba & $39.55 \pm 0.30^{\text {ba }}$ & $39.48 \pm 0.21^{b}$ \\
\hline Respiration rate $(\mathrm{RR}, \mathrm{r} / \mathrm{min})$ & $19.00 \pm 0.41^{b}$ & $124.0 \pm 0.95^{\mathrm{a}}$ & $118.0 \pm 2.58^{a}$ & $118.0 \pm 5.29^{a}$ & $26.0 \pm 1.15^{b}$ & $118.0 \pm 3.46^{\mathrm{a}}$ & $118.0 \pm 6.80^{a}$ & $117.0 \pm 3.00^{\circ}$ \\
\hline
\end{tabular}

In the same row means with different superscripts are significantly different $(P<0.05)$.

Table 3. Homatological picture, hematocrite $(\mathrm{Ht}, \%)$, hemoglobin $(\mathrm{Hb}, \mathrm{g} / \mathrm{dl})$, red blood cells count (RBCs, X 106/mm3) and white blood cells count (WBCs, X 103/mm3) during zero time and first three days for buffalo calves exposured to first and second thermal shock $\left(40^{\circ} \mathrm{C}\right)$.

\begin{tabular}{|c|c|c|c|c|c|c|c|c|}
\hline \multirow{3}{*}{ Items } & \multirow{3}{*}{$\begin{array}{c}\text { First } \\
\text { Zero day } \\
26^{\circ} \mathrm{C}\end{array}$} & \multicolumn{3}{|c|}{ First Shock $40^{\circ} \mathrm{C}$} & \multirow{3}{*}{$\begin{array}{c}\text { Second } \\
\text { Zero day } \\
27^{\circ} \mathrm{C}\end{array}$} & \multicolumn{3}{|c|}{ Second Shock $40^{\circ} \mathrm{C}$} \\
\hline & & \multicolumn{3}{|c|}{ Days } & & \multicolumn{3}{|c|}{ Days } \\
\hline & & 1 & 2 & 3 & & 1 & 2 & 3 \\
\hline Hematocrite $(\mathrm{Ht}, \%)$ & $32.80 \pm 0.90^{\mathrm{a}}$ & $28.80 \pm 0.50^{\text {ba }}$ & $29.80 \pm 0.30^{\text {ba }}$ & $27.0 \pm 1.22^{b}$ & $31.60 \pm 3.59$ ba & $30.30 \pm 2.90^{\text {ba }}$ & $30.30 \pm 1.03^{\mathrm{ba}}$ & $29.50 \pm 0.29$ ba \\
\hline Hemoglobin $(\mathrm{Hb}, \mathrm{g} / \mathrm{dl})$ & $11.68 \pm 0.48^{a}$ & $10.30 \pm 0.30^{\mathrm{bc}}$ & $10.28 \pm 0.20^{b c}$ & $9.80 \pm 0.13^{c}$ & $11.30 \pm 0.21$ ba & $10.80 \pm 0.60^{c}$ & $10.30 \pm 0.19^{b c}$ & $10.20 \pm 0.10^{b c}$ \\
\hline $\begin{array}{l}\text { Red blood cells count } \\
\left(\text { RBCs, } \times 10^{6} / \mathrm{mm}^{3}\right)\end{array}$ & $6.70 \pm 0.10^{\mathrm{a}}$ & $5.90 \pm 0.21 \mathrm{bc}$ & $5.70 \pm 0.19 \mathrm{bcd}$ & $5.30 \pm 0.21^{\mathrm{cd}}$ & $6.20 \pm 0.10$ ba & $6.30 \pm 0.30$ ba & $5.70 \pm 0.21 \mathrm{bcd}$ & $5.80 \pm 0.28 \mathrm{bc}$ \\
\hline $\begin{array}{l}\text { White blood cells count } \\
\left(\text { WBCs, } \times 10^{3} / \mathrm{mm}^{3}\right)\end{array}$ & $2.30 \pm 0.10^{d}$ & $2.70 \pm 0.10^{\mathrm{bcd}}$ & $2.70 \pm 0.10^{\mathrm{bc}}$ & $3.00 \pm 0.21$ ba & $2.90 \pm 0.14$ ba & $3.10 \pm 0.03^{a}$ & $3.20 \pm 0.20^{a}$ & $3.50 \pm 0.15^{\mathrm{a}}$ \\
\hline
\end{tabular}

In the same row means with different superscripts are significantly different $(P<0.05)$. 
Table 4. Percentages of leukocytes types neutrophils (Ne), lymphocyte (Ly), eosinophils (Eo), monocytes (Mo) and basophils (Ba) during zero time and first three days for buffalo calves exposured to first and second thermal shock $\left(40^{\circ} \mathrm{C}\right)$.

\begin{tabular}{|c|c|c|c|c|c|c|c|c|}
\hline \multirow{3}{*}{ Items } & \multirow{3}{*}{$\begin{array}{c}\text { First } \\
\text { Zero day } \\
26^{\circ} \mathrm{C}\end{array}$} & \multicolumn{3}{|c|}{ First Shock $40^{\circ} \mathrm{C}$} & \multirow{3}{*}{$\begin{array}{c}\text { Second } \\
\text { Zero day } \\
27^{\circ} \mathrm{C}\end{array}$} & \multicolumn{3}{|c|}{ Second Shock $40^{\circ} \mathrm{C}$} \\
\hline & & \multicolumn{3}{|c|}{ Days } & & \multicolumn{3}{|c|}{ Days } \\
\hline & & 1 & 2 & 3 & & 1 & 2 & 3 \\
\hline Neutrophils ( $\mathrm{Ne}$ ) & $40.88 \pm 2.1^{\text {ba }}$ & $53.5 \pm 1.85^{\mathrm{a}}$ & $52.5 \pm 0.15^{\mathrm{a}}$ & $54.00 \pm 1.58^{a}$ & $51.70 \pm 1.30^{\mathrm{b}}$ & $53.25 \pm 1.60^{a}$ & $53.00 \pm 1.41^{a}$ & $52.00 \pm 1.42^{\mathrm{a}}$ \\
\hline Lymphocyte (Ly) & $49.75 \pm 0.22$ ba & $36.0 \pm 1.41^{a}$ & $37.254 \pm 0.75^{\mathrm{a}}$ & $36.00 \pm 1.60^{a}$ & $38.4 \pm 1.07^{b}$ & $35.75 \pm 1.34^{\mathrm{a}}$ & $36.05 \pm 0.57^{a}$ & $36.99 \pm 0.57^{\mathrm{a}}$ \\
\hline Eosinophils (Eo) & $4.50 \pm 0.30$ ba & $4.50 \pm 0.25^{a}$ & $3.50 \pm 0.29^{a}$ & $3.00 \pm 0.50^{\mathrm{a}}$ & $4.46 \pm 0.20^{b}$ & $4.50 \pm 0.25^{a}$ & $4.75 \pm 0.05^{\mathrm{a}}$ & $4.75 \pm 0.05^{a}$ \\
\hline Monocytes (Mo) & $4.87 \pm 0.60$ ba & $6.00 \pm 0.71$ ba & $6.75 \pm 0.10$ ba & $6.75 \pm 0.25$ ba & $5.30 \pm 0.42^{b}$ & $6.25 \pm 0.50$ ba & $6.00 \pm 1.48^{\mathrm{b}}$ & $6.01 \pm 1.48^{\mathrm{b}}$ \\
\hline Basophils (Ba) & $0.0 \pm 0.0^{a}$ & $0.0 \pm 0.0^{a}$ & $0.0 \pm 0.0^{a}$ & $0.25 \pm 0.25^{\mathrm{a}}$ & $0.14 \pm 0.14^{\mathrm{ab}}$ & $0.25 \pm 0.25^{\mathrm{a}}$ & $0.25 \pm 0.25^{\mathrm{a}}$ & $0.25 \pm 0.29^{a}$ \\
\hline
\end{tabular}

In the same row means with different superscripts are significantly different $(P<0.05)$.

Table 5. Water intake (WI, l/day) and feed intake (FI, kg/day) (concentrate (Con), wheat straw (R1) and barseem hay (R2)) during zero time and first three days for buffalo calves exposured to first and second thermal shock $\left(40^{\circ} \mathrm{C}\right)$.

\begin{tabular}{|c|c|c|c|c|c|c|c|c|}
\hline \multirow{3}{*}{ Items } & \multirow{3}{*}{$\begin{array}{c}\text { First } \\
\text { Zero day } \\
26^{\circ} \mathrm{C}\end{array}$} & \multicolumn{3}{|c|}{ First Shock $40^{\circ} \mathrm{C}$} & \multirow{3}{*}{$\begin{array}{c}\text { Second } \\
\text { Zero day } \\
27^{\circ} \mathrm{C}\end{array}$} & \multicolumn{3}{|c|}{ Second Shock $40^{\circ} \mathrm{C}$} \\
\hline & & \multicolumn{3}{|c|}{ Days } & & \multicolumn{3}{|c|}{ Days } \\
\hline & & 1 & 2 & 3 & & 1 & 2 & 3 \\
\hline Water intake (WI, I/day) & $18.30 \pm 0.60^{b}$ & $19.80 \pm 1.70^{b}$ & $22.50 \pm 1.40^{b}$ & $21.30 \pm 1.70^{b}$ & $18.80 \pm 0.50^{b}$ & $21.00 \pm 3.20^{b}$ & $24.00 \pm 3.70^{b}$ & $19.5 \pm 3.18^{b}$ \\
\hline Concentrate (Con, kg/day) & $2.00 \pm 0.20^{b}$ & $1.30 \pm 0.12^{\mathrm{cd}}$ & $1.19 \pm 0.20^{\mathrm{d}}$ & $1.00 \pm 0.10^{\mathrm{cbd}}$ & $2.30 \pm 0.00^{\mathrm{a}}$ & $1.90 \pm 0.30 \mathrm{cb}$ & $2.30 \pm 0.00^{\mathrm{a}}$ & $2.50 \pm 0.13^{a}$ \\
\hline Wheat straw $(\mathrm{R} 1, \mathrm{~kg} /$ day $)$ & $0.38 \pm 0.10^{b}$ & $0.56 \pm 0.10^{b}$ & $0.56 \pm 0.10^{b}$ & $0.56 \pm 0.10^{b}$ & $1.0 \pm 0.00^{a}$ & $0.50 \pm 0.00^{b}$ & $0.50 \pm 0.00^{b}$ & $0.50 \pm 0.10^{b}$ \\
\hline Barseem hay $(\mathrm{R} 2, \mathrm{~kg} /$ day $)$ & $0.25 \pm 0.00^{a}$ & $0.19 \pm 0.04^{a}$ & $0.21 \pm 0.04^{a}$ & $0.25 \pm 0.00^{a}$ & $0.25 \pm 0.00^{a}$ & $0.25 \pm 0.00^{a}$ & $0.25 \pm 0.00^{a}$ & $0.25 \pm 0.00^{a}$ \\
\hline
\end{tabular}

In the same row means with different superscripts are significantly different $(P<0.05)$. 
Table 6. Total lipids ( $T L, \mathrm{mg} / \mathrm{dl})$, total cholesterol (TC, mg/dl), triglyceride (TG, mg/dl), total protein (TP, g/dl), albumin (Alb, g/dl), globulin (Glb, g/dl), glucose $(\mathrm{Glu}, \mathrm{mg} / \mathrm{dl})$, blood urea nitrogen (BUR, $\mathrm{mg} / \mathrm{dl})$ and creatinine $(\mathrm{C}, \mathrm{mg} / \mathrm{dl})$ during zero time and first three days for buffalo calves exposured to first and second thermal shock $\left(40^{\circ} \mathrm{C}\right)$.

\begin{tabular}{|c|c|c|c|c|c|c|c|c|}
\hline \multirow{3}{*}{ Items } & \multirow{3}{*}{$\begin{array}{c}\text { First } \\
\text { Zero day } \\
26^{\circ} \mathrm{C}\end{array}$} & \multicolumn{3}{|c|}{ First Shock $40^{\circ} \mathrm{C}$} & \multirow{3}{*}{$\begin{array}{c}\text { Second } \\
\text { Zero day } \\
27^{\circ} \mathrm{C}\end{array}$} & \multicolumn{3}{|c|}{ Second Shock $40^{\circ} \mathrm{C}$} \\
\hline & & \multicolumn{3}{|c|}{ Days } & & \multicolumn{3}{|c|}{ Days } \\
\hline & & 1 & 2 & 3 & & 1 & 2 & 3 \\
\hline Total lipids $(\mathrm{TL}, \mathrm{mg} / \mathrm{dl})$ & $493.0 \pm 0.12^{a}$ & $320.0 \pm 0.08^{b}$ & $236.0 \pm 0.06^{\text {dce }}$ & $217.0 \pm 0.04 \mathrm{fe}$ & $259.0 \pm 0.165^{c}$ & $254.0 \pm 0.03^{\mathrm{dc}}$ & $230.0 \pm 0.05$ dfe & $206.0 \pm 0.08^{f}$ \\
\hline Total cholesterol (TC, mg/dl) & $71.86 \pm 3.88^{a}$ & $62.84 \pm 0.78^{a}$ & $50.67 \pm 3.31^{\mathrm{b}}$ & $42.62 \pm 3.08^{\mathrm{cb}}$ & $37.96 \pm 0.52^{c}$ & $47.3 \pm 5.95^{\mathrm{cb}}$ & $40.86 \pm 4.55^{c b}$ & $36.24 \pm 1.83^{c}$ \\
\hline Triglyceride $(\mathrm{TG}, \mathrm{mg} / \mathrm{dl})$ & $76.29 \pm 0.65^{\mathrm{a}}$ & $73.72 \pm 1.03^{\mathrm{bc}}$ & $71.14 \pm 2.16^{\mathrm{c}}$ & $62.68 \pm 0.94^{d}$ & $75.16 \pm 1.98^{\mathrm{bac}}$ & $78.77 \pm 1.10^{a}$ & $75.37 \pm 0.85^{\text {bac }}$ & $71.68 \pm 1.00^{\mathrm{dc}}$ \\
\hline Total protein $(T P, g / d l)$ & $9.70 \pm 0.01^{\mathrm{a}}$ & $9.37 \pm 0.23$ ba & $8.70 \pm 0.34$ bc & $7.92 \pm 0.10^{d}$ & $8.59 \pm 0.28 \mathrm{dc}$ & $8.96 \pm 0.40^{b c}$ & $8.26 \pm 0.09 \mathrm{dc}$ & $8.22 \pm 0.05^{d c}$ \\
\hline Albumin (Alb, g/dl) & $5.03 \pm 0.02^{\mathrm{a}}$ & $4.68 \pm 0.18^{\text {ba }}$ & $4.47 \pm 0.17^{b}$ & $3.90 \pm 0.17^{c}$ & $3.95 \pm 0.18^{\mathrm{c}}$ & $4.26 \pm 0.06^{\mathrm{bc}}$ & $3.99 \pm 0.16^{c}$ & $3.79 \pm 0.16^{c}$ \\
\hline Globulin (Glb, g/dl) & $4.68 \pm 0.03^{a}$ & $4.69 \pm 0.34^{\mathrm{a}}$ & $4.23 \pm 0.41^{\mathrm{a}}$ & $4.02 \pm 0.23^{\mathrm{a}}$ & $4.64 \pm 0.38^{a}$ & $4.70 \pm 0.44^{a}$ & $4.27 \pm 0.23^{a}$ & $4.43 \pm 0.14^{\mathrm{a}}$ \\
\hline Glucose (Glu, mg/dl) & $76.31 \pm 0.85^{a}$ & $61.91 \pm 6.65^{b}$ & $55.38 \pm 5.55^{\mathrm{cb}}$ & $50.17 \pm 6.02^{\mathrm{cb}}$ & $56.40 \pm 0.73^{b}$ & $53.43 \pm 5.27^{\mathrm{cb}}$ & $49.24 \pm 1.19^{\mathrm{cb}}$ & $40.72 \pm 3.00^{c}$ \\
\hline Blood urea nitrogen (BUR, mg/dl) & $43.77 \pm 1.14^{\mathrm{a}}$ & $38.67 \pm 0.61^{b}$ & $34.55 \pm 0.51^{\mathrm{c}}$ & $31.95 \pm 0.46^{d c}$ & $33.82 \pm 1.36^{\mathrm{dc}}$ & $33.52 \pm 2.68^{d c}$ & $29.78 \pm 0.83^{d}$ & $29.66 \pm 0.79^{d}$ \\
\hline
\end{tabular}

In the same row means with different superscripts are significantly different $(P<0.05)$.

Table 7. Insulin (Ins, $\mu \mathrm{IU} / \mathrm{ml}$ ), glucagons ( $\mathrm{Glg}, \mathrm{pg} / \mathrm{ml})$, triiodothyronine $(\mathrm{T} 3, \mathrm{ng} / \mathrm{dl})$, thyroxine ( $\mathrm{T4}$, $\mu \mathrm{g} / \mathrm{dl})$ and aldosterone (Al, pg/dl) during zero time and first three days for buffalo calves exposured to first and second thermal shock $\left(40^{\circ} \mathrm{C}\right)$.

\begin{tabular}{|c|c|c|c|c|c|c|c|c|}
\hline \multirow{3}{*}{ Items } & \multirow{3}{*}{$\begin{array}{c}\text { First } \\
\text { Zero day } \\
26^{\circ} \mathrm{C}\end{array}$} & \multicolumn{3}{|c|}{ First Shock $40^{\circ} \mathrm{C}$} & \multirow{3}{*}{$\begin{array}{c}\text { Second } \\
\text { Zero day } \\
27^{\circ} \mathrm{C}\end{array}$} & \multicolumn{3}{|c|}{ Second Shock $40^{\circ} \mathrm{C}$} \\
\hline & & \multicolumn{3}{|c|}{ Days } & & \multicolumn{3}{|c|}{ Days } \\
\hline & & 1 & 2 & 3 & & 1 & 2 & 3 \\
\hline Insulin (Ins, $\mu \mathrm{IU} / \mathrm{ml})$ & $30.36 \pm 1.39^{a}$ & $26.38 \pm 0.37^{b}$ & $22.66 \pm 0.49^{\text {ced }}$ & $20.09 \pm 0.31^{\mathrm{e}}$ & $25.25 \pm 1.25^{\mathrm{cb}}$ & $24.32 \pm 1.40^{\mathrm{cbd}}$ & $23.08 \pm 0.93^{\text {ced }}$ & $21.84 \pm 0.57^{\text {ed }}$ \\
\hline Glucagons (Glg, pg/ml) & $46.30 \pm 3.62^{a}$ & $44.74 \pm 4.20^{\mathrm{a}}$ & $42.31 \pm 1.89^{a}$ & $93.83 \pm 2.54^{\mathrm{a}}$ & $31.43 \pm 12.11^{a}$ & $42.56 \pm 7.73^{a}$ & $41.51 \pm 3.63^{\mathrm{a}}$ & $44.20 \pm 3.81^{a}$ \\
\hline Triiodothyronine $\left(T_{3}, \mathrm{ng} / \mathrm{dl}\right)$ & $148.40 \pm 1.24^{a}$ & $137.35 \pm 2.89^{b}$ & $127.80 \pm 2.22^{\mathrm{cd}}$ & $118.43 \pm 1.27^{\mathrm{e}}$ & $123.5 \pm 3.84^{\text {ed }}$ & $134.19 \pm 2.00^{\mathrm{cb}}$ & $132.14 \pm 1.83^{\mathrm{cb}}$ & $123.29 \pm 1.14^{\mathrm{ed}}$ \\
\hline Thyroxine $\left(T_{4}, \mu \mathrm{g} / \mathrm{dl}\right)$ & $4.76 \pm 0.29^{a}$ & $3.86 \pm 0.23^{b}$ & $3.03 \pm 0.13^{c}$ & $2.46 \pm 0.22^{d}$ & $2.88 \pm 0.12^{\mathrm{dc}}$ & $3.02 \pm 0.05^{c}$ & $2.93 \pm 0.04 \mathrm{dc}$ & $2.70 \pm 0.14^{\mathrm{dc}}$ \\
\hline Aldosterone (Al, pg/dl) & $58.65 \pm 21.69^{a}$ & $46.28 \pm 21.72^{a}$ & $43.95 \pm 0.68^{a}$ & $35.93 \pm 11.93^{a}$ & $50.70 \pm 13.17^{\mathrm{a}}$ & $44.63 \pm 2.74^{a}$ & $56.55 \pm 10.51^{a}$ & $53.82 \pm 10.61^{a}$ \\
\hline
\end{tabular}

In the same row means with different superscripts are significantly different $(P<0.05)$. 


\begin{tabular}{|c|c|c|c|c|}
\hline \multirow{9}{*}{$\begin{array}{l}\bar{U} \\
\stackrel{0}{\simeq}\end{array}$} & 100 & & 3 & \\
\hline & 98 & & 2.5 & \\
\hline & 96 & & & \\
\hline & 94 & & & \\
\hline & 92 & & & $\propto$ \\
\hline & 90 & & 1 & \\
\hline & 88 & & 0.5 & \\
\hline & 86 & & 0 & \\
\hline & First shock & $\begin{array}{c}\text { Second } \\
\text { shock }\end{array}$ & & \\
\hline
\end{tabular}

Fig. 1. Change between zero and third days from thermal shock $\left(40^{\circ} \mathrm{C}\right)$ for rectal temperature $\left(R T,{ }^{\circ} \mathrm{C}\right)$ and respiration rate $(R R, r / m i n)$ for buffalo calves exposures.

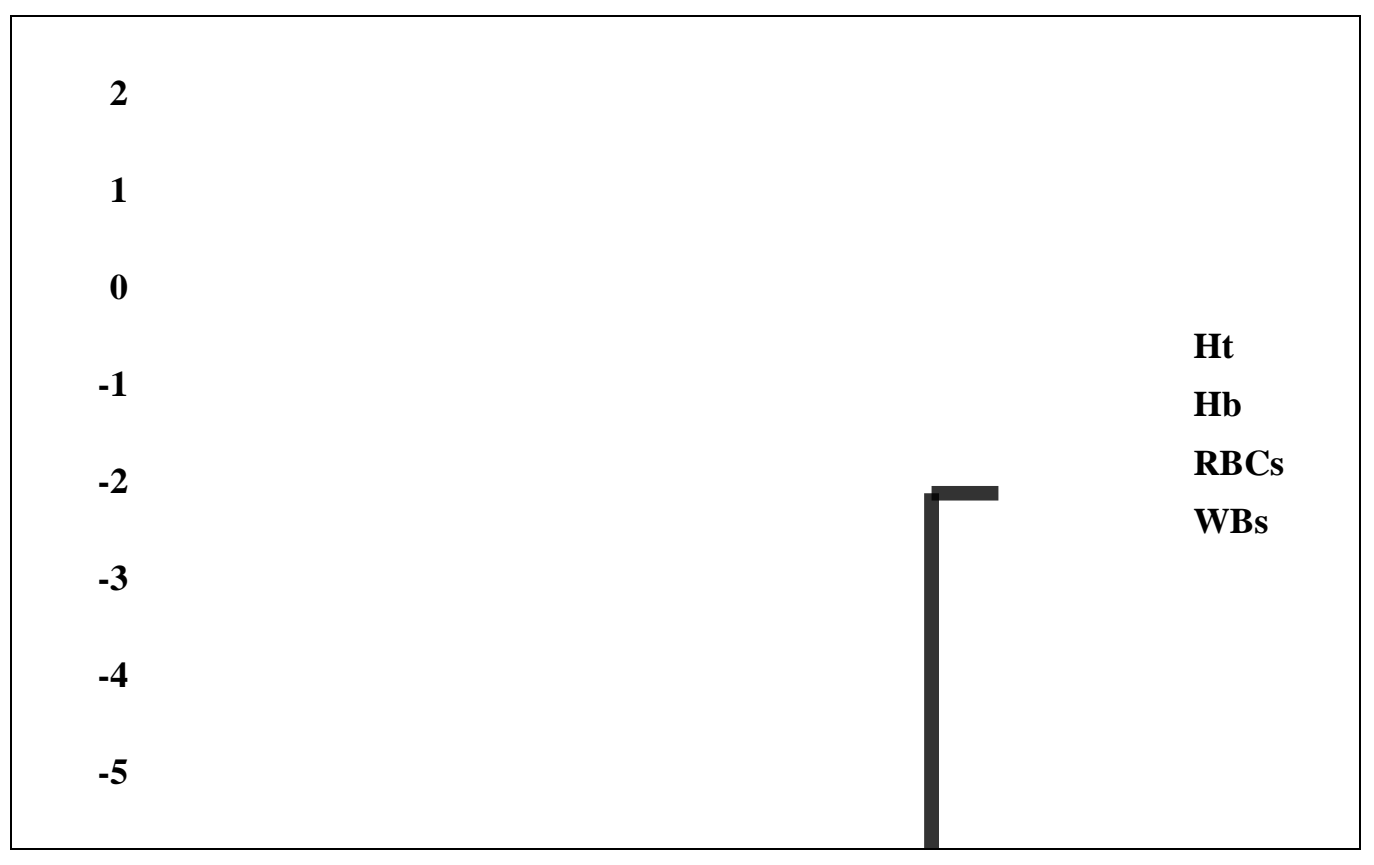

Fig. 2. Change between zero and third days from thermal shock $\left(40^{\circ} \mathrm{C}\right)$ for hematocrite $(\mathrm{Ht}, \%)$, hemoglobin $(\mathrm{Hb}, \mathrm{g} / \mathrm{dl})$, red blood cells count (RBCs, $\mathrm{X}$ $10^{6} / \mathrm{mm}^{3}$ ) and white blood cells count (WBCs, $\times 10^{3} / \mathrm{mm}^{3}$ ) for buffalo calves exposures. 


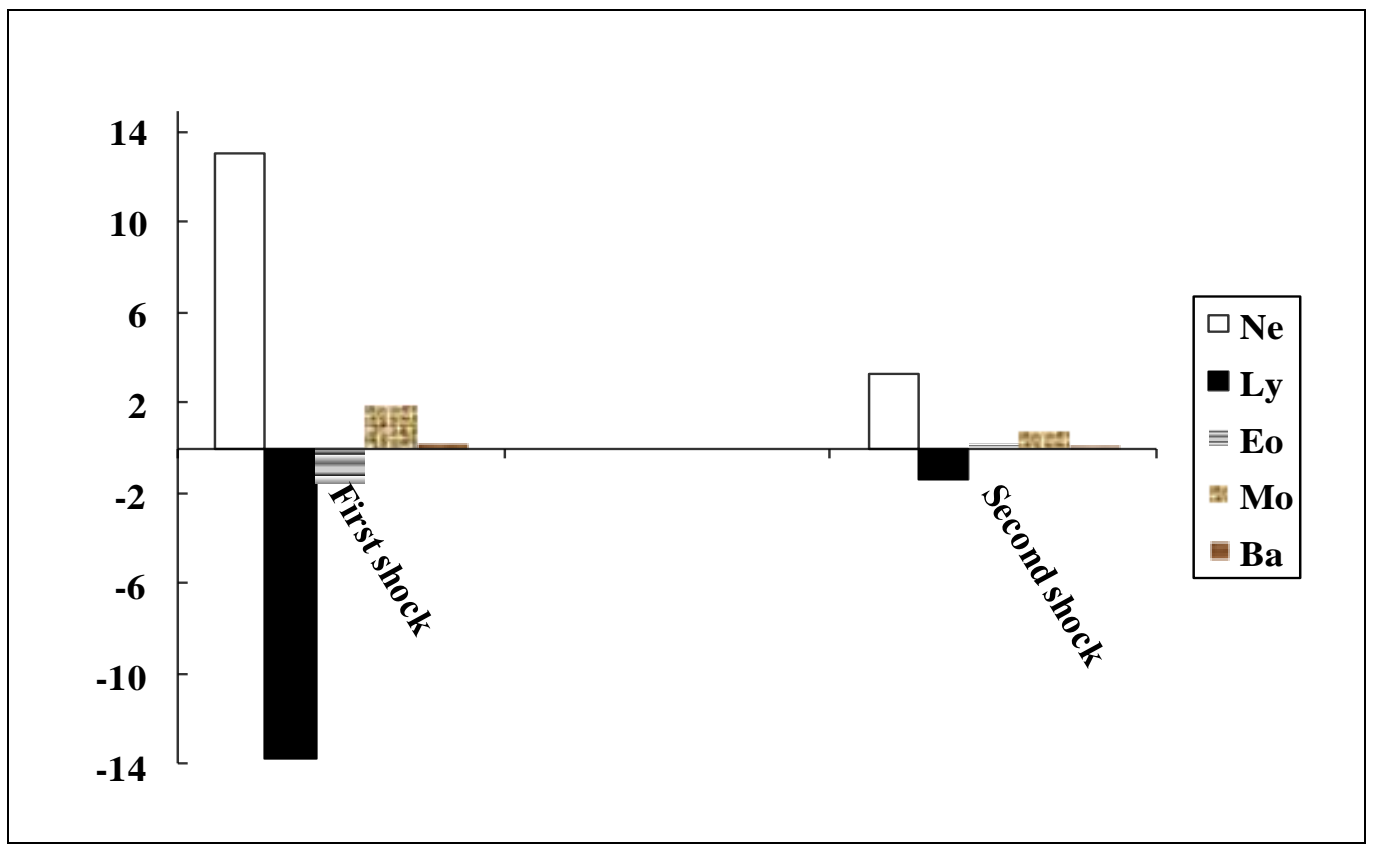

Fig. 3. Change between zero and third days from thermal shock $\left(40^{\circ} \mathrm{C}\right)$ for percentages of leukocytes types neutrophils ( $\mathrm{Ne}$ ), lymphocyte (Ly), eosinophils (Eo), monocytes (Mo) and basophils (Ba) for buffalo calves exposures.

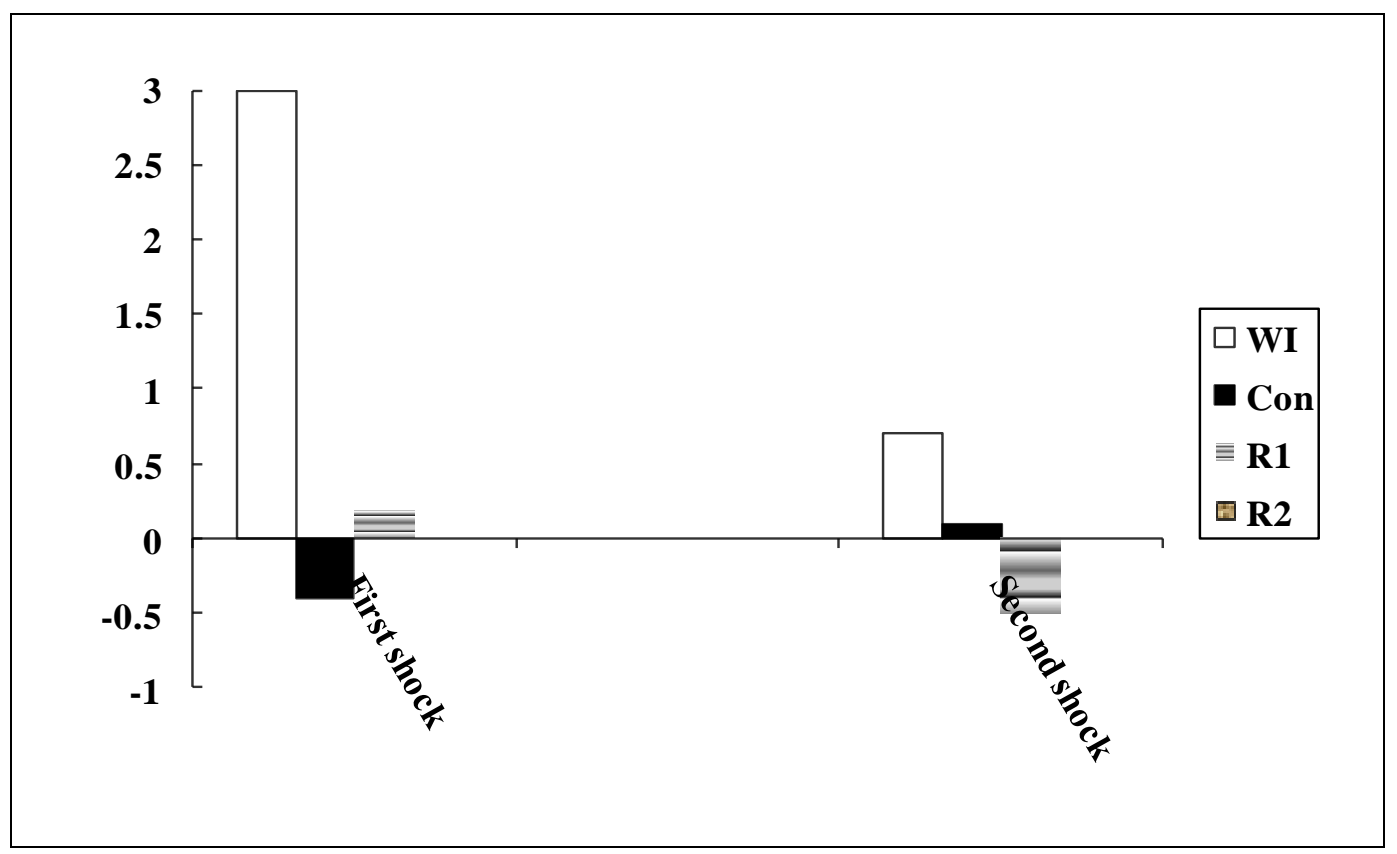

Fig. 4. Change between zero and third days from thermal shock $\left(40^{\circ} \mathrm{C}\right)$ for water intake (WI, I/day) and feed intake (FI, kg/day) (concentrate, Con), wheat straw (R1) and barseem hay (R2) for buffalo calves exposures. 


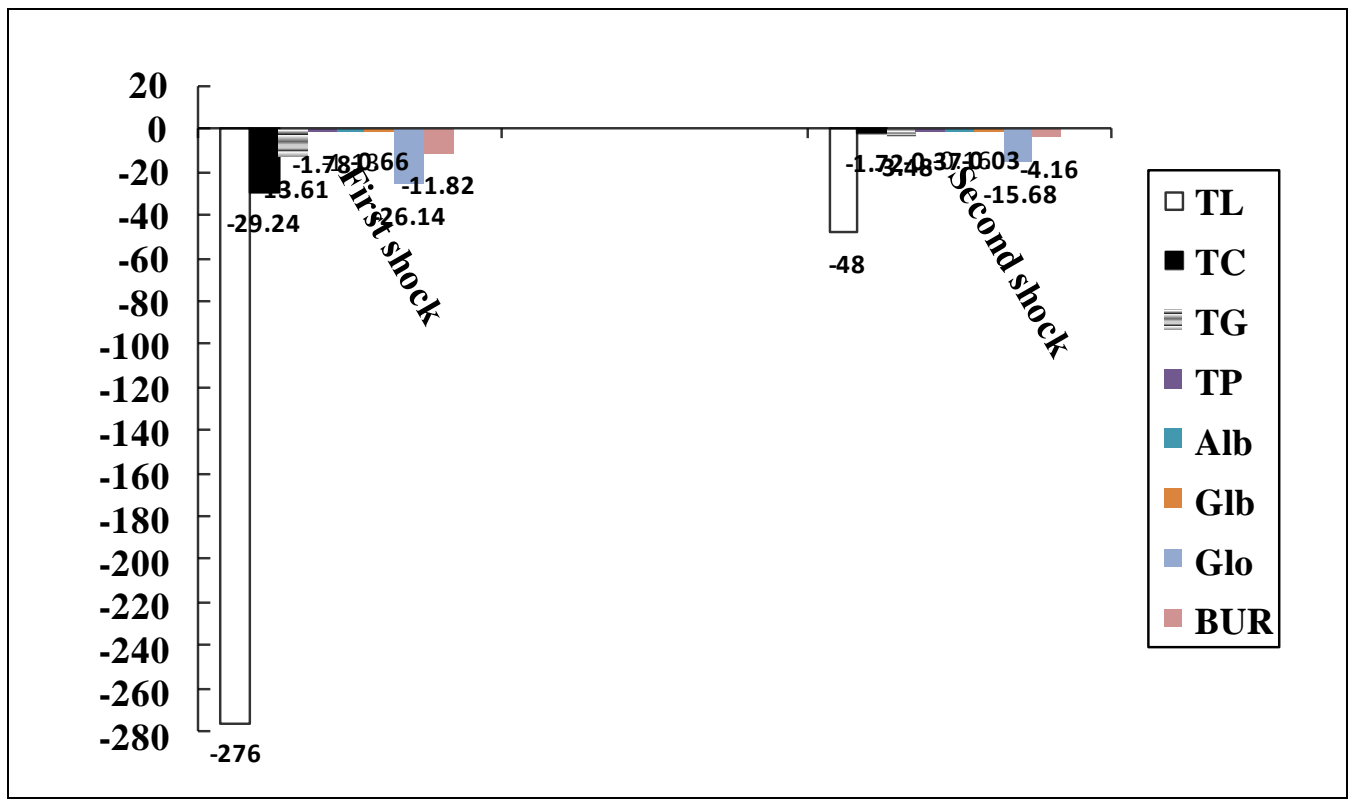

Fig. 5. Change between zero and third days from thermal shock $\left(40^{\circ} \mathrm{C}\right)$ for total lipids $(\mathrm{TL}, \mathrm{mg} / \mathrm{dl})$, total cholesterol $(\mathrm{TC}, \mathrm{mg} / \mathrm{dl})$, triglyceride $(\mathrm{TG}, \mathrm{mg} / \mathrm{dl})$, total protein (TP, g/dl), albumin (Alb, g/dl), globulin (Glb, g/dl), glucose (Glu, $\mathrm{mg} / \mathrm{dl}$ ) and blood urea nitrogen (BUR, $\mathrm{mg} / \mathrm{dl}$ ) for buffalo calves exposures.

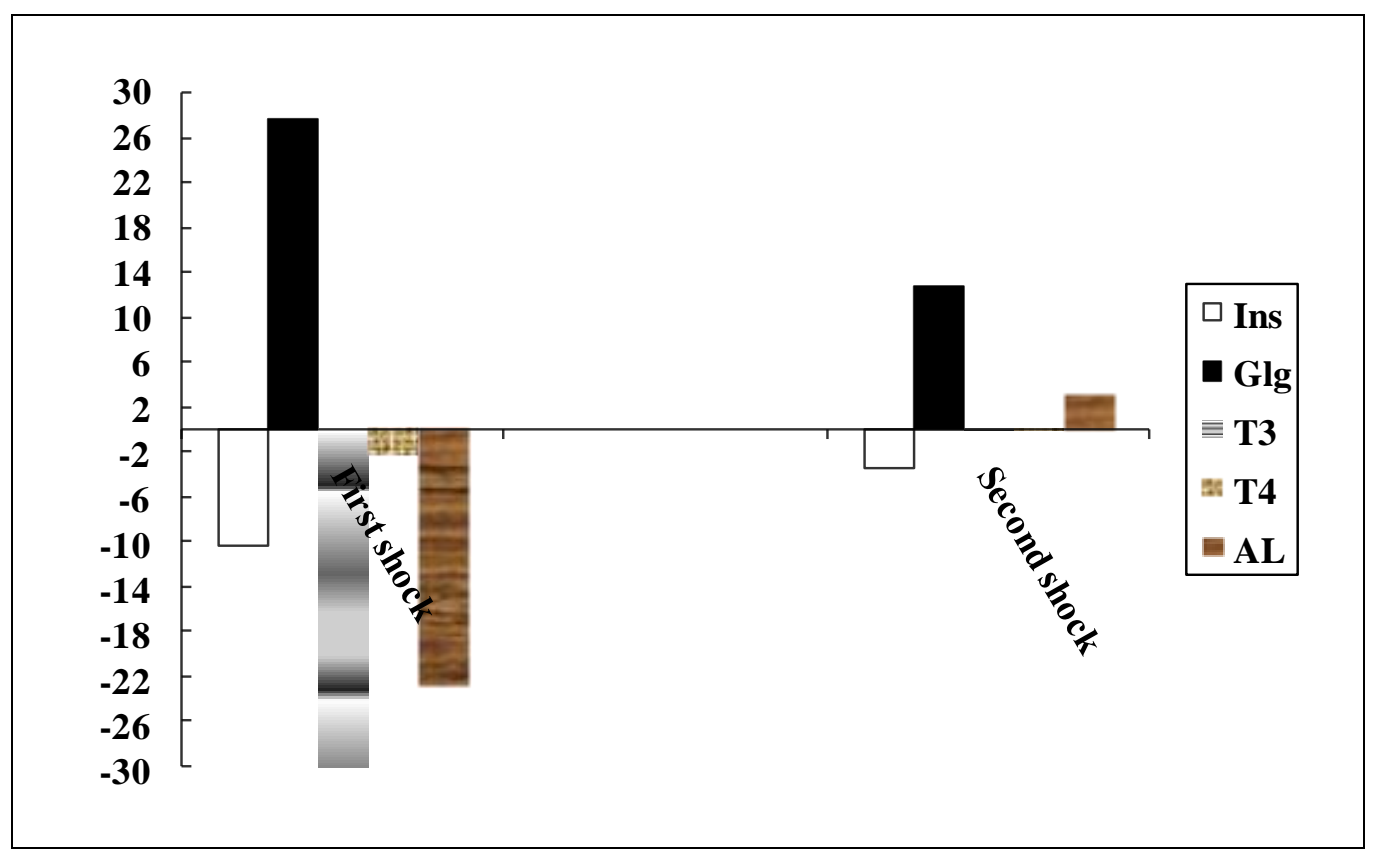

Fig. 6. Change between zero and third days from thermal shock $\left(40^{\circ} \mathrm{C}\right)$ for insulin (Ins, $\mu \mathrm{IU} / \mathrm{ml})$, glucagons $(\mathrm{Glg}, \mathrm{pg} / \mathrm{ml})$, triiodothyronine $\left(T_{3}, \mathrm{ng} / \mathrm{dl}\right)$, thyroxine $\left(T_{4}, \mu \mathrm{g} / \mathrm{dl}\right)$ and aldosterone (Al, pg/dl) for buffalo calves exposures. 


\section{REFERENCES}

1. Ashoir, G., F. I. Omran, M. M. Yousef and M. M. Shafie. 2007. Effect of thermal environment on water and feed intakes in relationship with growth of buffalo calves. Egyptian J. Anim. Prod., 44 (1): 25-33.

2. Baccari, F. JR., A. C. Blasi, M. R. Muniz and C. A. Fre. 1990. Effect of thermal stress on feed intake and serum triiodothyronine in young buffaloe bulls. Proc. II World Buffalo Congress, 12-16 December, 1988, New Delhi. Indian, P. 139.

3. Collier, R. J., J. L. Collier, R. P. Rhoads and L. H. Baumgard. 2008. Invited review: Genes involved in the bovine heat stress response. J. Dairy Sci., 91: 445454.

4. Fooda, T. A. 2005. Possibilities of improving 12-month weight of Egyptian buffaloes by selection index. Ph. D. Thesis, Fac. Agric., Ain Shams Univ., Cairo, Egypt, 83 PP.

5. Haque, N., A. Ludri, S. A. Hossain and M. Ashutosh. 2012. Alteration of metabolic profiles in young and adult murrah buffaloes exposed to acute heat stress. International J. of Applied Animal Sci., Vol. 1 (1): 23-29.

6. Jain, N. C., J. L. Vegad, N. K. Jain and A. B. Srivastava. 1982. Cited by Chaudry, M. N. et al. (1995).

7. Kundu, A. K. and D. S. Bhatnagar. 1980. Physiological reactions in different genetic groups of crossbreds during summer. Indian J. Dairy Sci., $33: 403$.

8. Mullick, D. N. 1962. A study on the metabolism of food nutrients in cattle and buffalo bulls under climatic stress. Proc. Symp. Environ. Physiol. Psychol. Arid Cand. UNESCO, New York, 137.

9. Nangia, O. P. and S. L. Gary. 1992. Environmental changes in the energy yielding blood metabolites and their relation to voluntary feed intake in buffaloes. Indian J. Dairy Sci., 54 : P. 6.

10. Omran, Fayza I. 1999. Physiological reaction and growth performance of buffaloes and Friesian calves to heat stress. M. Sc. Thesis, Fac. Agric., Cairo Univ., Giza, Egypt, P 147.

11. Omran, Fayza I. 2008. Impact of thermo-physiological reaction on growth performance of buffalo calves. Ph. D. Thesis, Fac. Agric., Cairo Univ., Giza, Egypt, P 142.

12. Omran, Fayza I. and T. A. Fooda. 2012. Growth performance and physiological response for buffalo calves under different environmental conditions. Egypt J. Agric. Res., 90 (3), 2012. 
13. Omran Fayza I., G. Ashour, M.M. Youssef and M. M. Shafie. 2011. Responses of hematology, blood metabolites, mineral ions and hormonal profile to heat stress for Egyptian buffalo-calves. Egypt J. Agric. Res., 89(3). 1129-1140.

14. SAS (2002). Statistical Analysis System Institute, Inc., Cary, Nc., USA.

15. Shafie, M. M. and A. L. Badreldin. 1962. The role of blood in regulating body heat in bovines. Egyptian J. Anim. Prod., $2: 62$.

16. Shafie, M. M. 1993a. Biological adaptation of buffaloes to climatic conditions. As for Ashour, 1993., 176.

17. Thanh, T. K. and W. S. Chang. 2007. Differences in adaptation to tropical weather between buffaloes and cattle. Ital. J. Anim. Sci. 6 (2): 1340-1343.

18. West, J. W. 2003. Effects of heat-stress on production in dairy cattle. J. Dairy Sci., 86: 2131.

19. Yousef, H. M. 1990. Studies on adaptation of Friesian cattle in Egypt. Ph. D. Thesis, Fac. Agric., Zagazig Univ., Zagazig, Egypt, P.175. 


\section{إستجابة عجول الجاموس المعرضة للصدمة الحرارية الأولي والثانية}

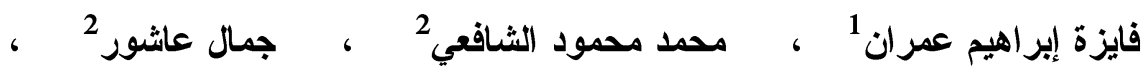

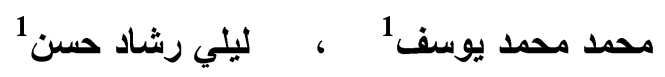

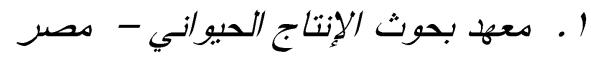

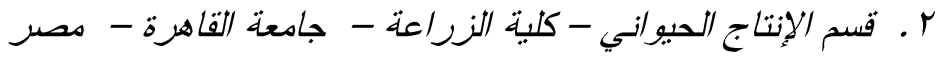

4 عجول جاموس كانت متاحة لهذا العمل أعمار هم كانت 6 شهور و أوز انهم تر اوحت ما بين 118- 119 كجم و أجريت هذه الدراسة بمعمل فسيولوجيا الحيوان، قسم الإنتاج الحيو اني، كلية الزر اعة، جامعة القاهرة. وكان الهدف من هذه الدراسة هو مقارنة استجابة عجول الجاموس

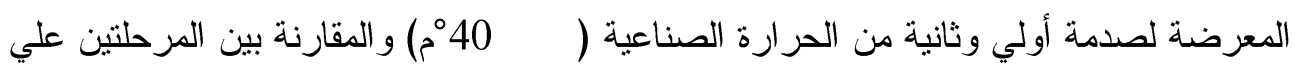
الاستجابة للظو اهر الفسيولوجية و هيماتولوجي الدم وبعض مكونات الدام و الهرمونات و المأكول من

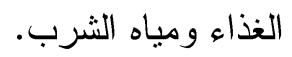

يمكن تلخيص النتائج التي نم الحصول عليها من هذه الدراسة على النحو التالي أن الصدمة

الحرارية الثانية كانت أقل عنف من الصدمة الحرارية الأولي. وكان ثبات معدل التتفس في الصدمة

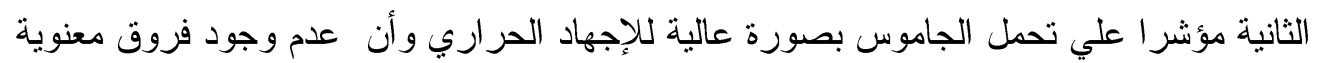

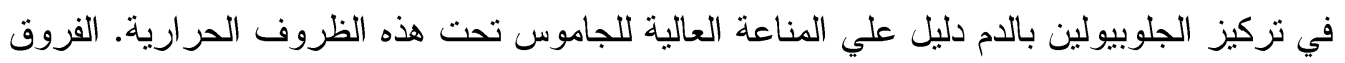

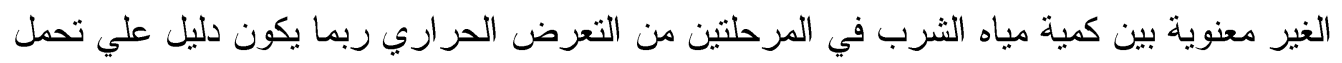
الجاموس لنقص المياه وهذا يحتاج إلي العديد من الدراسات لتأكيد ذلك. ويمكن القول أن الجاموس لئس

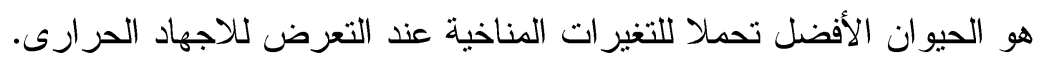

